\title{
Incorporation of anti-inflammatory agent into calcium hydroxide pulp capping material: An in vitro study of physical and mechanical properties
}

\author{
Phumisak LOUWAKUL ${ }^{1}$ and Veera LERTCHIRAKARN ${ }^{2}$ \\ ${ }^{1}$ Dental Biomaterials Science, Graduate School, Chulalongkorn University, Patumwan, Bangkok, 10330, THAILAND \\ ${ }^{2}$ Department of Microbiology, Faculty of Dentistry, Chulalongkorn University, Patumwan, Bangkok, 10330, THAILAND \\ Corresponding author, Veera LERTCHIRAKARN; E-mail: veera.l@chula.ac.th
}

\begin{abstract}
The aims of this study were to investigate the release of fluocinolone acetonide from an experimental pulp capping material containing fluocinolone acetonide (PCFA) and compare some physical and mechanical properties with Dycal ${ }^{\circledR}$. The PCFA is a hard-setting calcium hydroxide cement composed of $50 \mathrm{mmol} / \mathrm{L}$ fluocinolone acetonide. Conditioned media from the setting material was collected for determination of fluocinolone acetonide release by high performance liquid chromatography and $\mathrm{pH}$ measurement by $\mathrm{pH}$ meter. The setting time, compressive strength, disintegration, and acid soluble arsenic content were measured according to ISO 3107:2004. Dycal ${ }^{\circledR}$ was used as control. Fluocinolone acetonide could release at a range of suitable concentrations from PCFA. The pH, setting time, and acid soluble arsenic content of PCFA were significantly higher than those of Dycal ${ }^{\circledR}$. The compressive strength and disintegration of PCFA were comparable to control. PCFA may be considered as an alternative in pulp capping of inflamed dental pulp tissue.
\end{abstract}

Keywords: Calcium hydroxide, Dycal, Anti-inflammatory agent, Fluocinolone acetonide, Pulp capping

\section{INTRODUCTION}

Direct pulp capping or partial pulpotomy is a method of treatment in which the exposed dental pulp is covered with a material protecting the pulp from additional injury and permitting healing and repair. Materials used in vital pulp treatment must be placed in contact with the pulp tissue ${ }^{1,2)}$, so it should be nontoxic and biocompatible with the tissue. The pulp capping materials should also provide good sealing ability ${ }^{3,4)}$. The major problems with vital pulp therapy are the unpredictable severity of the inflammatory condition of the underlying tissue and variable long-term clinical success ${ }^{5,6)}$. Chronic inflammation in dental pulp tissue may lead ultimately to degenerative pulp response or pulp necrosis. To prevent these complications, the antiinflammatory agents have been used for treatment of deep carious lesion or pulpal exposure in permanent teeth with a mature apex ${ }^{7-10)}$. Anti-inflammatory medication mixed with a drug delivery vehicle would be an effective direct pulp-capping material for cariesexposed pulp tissue ${ }^{11)}$.

Anti-inflammatory agents, such as corticosteroids, has ability to inhibit inflammatory processes such as inhibition of hyperemia and edema, pain reduction, and presumably induction of pulpal healing ${ }^{7-10,12-14)}$. The use of topical corticosteroids in vital pulp treatment was first reported more than 50 years ago by Rapoport and Abramson ${ }^{9)}$, with $80-93 \%$ success in pulp capping procedures. However, a commercial product (Ledermix ${ }^{\circledR}$; Lederle Pharmaceuticals, Division of Cyanamid, Wolfratshausen, Germany) containing both 1\% triamcinolone acetonide and $3.21 \%$ demethylchlortetracycline in a zinc oxide-eugenol base, led to unpredictable and frequently unfavorable results $^{10,15-17)}$. This might be because uncontrolled release of the steroids which cause unpredictable long-term success and side effects. Recently, a number of evidence has shown the benefits of steroid usage for reduction inflammation and stimulation of pulp healing ${ }^{7,8,12,18)}$. Thus, short-term application of a corticosteroid to inflamed dental pulp can be considered to resolve inflammation and consequently promote healing ${ }^{18)}$.

Fluocinolone acetonide is a synthetic corticosteroid commonly used for topical application in the management of dermatologic disorders and oral vesiculoerosive lesions ${ }^{19-21)}$. The effects of fluocinolone acetonide on skin treatment are concentration-dependent. High concentrations of fluocinolone acetonide inhibited epidermal mitotic activity, but low concentrations slightly increased this activity ${ }^{22)}$. Increased proliferation of cultured human skin fibroblasts was noted over a wide range of concentration ${ }^{23)}$. Recently, a wide range of concentration of fluocinolone acetonide $(0.1-10 \mu \mathrm{mol} / \mathrm{L})$ demonstrated positive effects on human dental pulp cell proliferation, and both fibronectin and type I collagen synthesis ${ }^{18)}$. With the known anti-inflammatory effect, it may have some potential in stimulation of healing of dental pulp tissue before dentin bridge formation. Successful use of this agent in pulp treatment, however, requires careful control of corticosteroid release. Research interest has focused on the incorporation of fluocinolone acetonide into the pulp capping agent to promote healing of inflamed pulp tissue. The purposes of this study were to investigate the release of fluocinolone acetonide from an experimental pulp capping agent containing fluocinolone acetonide (PCFA) and compare some physical and mechanical properties between PCFA and commercial calcium hydroxide cement. 


\section{MATERIALS AND METHODS}

\section{Preparation of PCFA}

The components of PCFA, a two-paste calcium hydroxide cement containing base and catalyst, are shown in Table 1. All components of the PCFA and their roles as a pulp capping material are the same as the commercial hard setting calcium hydroxide cement (Dycal ${ }^{\circledR}$, Dentsply Inc., Milford, DE, USA), except fluocinolone acetonide which was added into PCFA as another active component. The fluocinolone acetonide powder (Fluocinolone acetonide, FARMABIOS S.R.L., Gropello Cairoli, Italy) was dissolved in dimethyl sulfoxide solution (DMSO; CHROMASOLV $^{\circledR}$ Plus, Sigma-Aldrich Corp., St. Louis, MO, USA) to obtain a 10, 20, 30, 40, 50, 75, 100, and 150 $\mathrm{mmol} / \mathrm{L}$ concentration before incorporation into the catalyst. The PCFA was stored at $4^{\circ} \mathrm{C}$ before use. Equal amount of the base and catalyst were mixed and allowed to set at room temperature to form hard setting calcium hydroxide cement. Dycal ${ }^{\mathbb{}}$ was used as a control (except in the in vitro release assay), and prepared in accordance with the manufacturer's instructions.

\section{In vitro release of fluocinolone acetonide}

The in vitro release of fluocinolone acetonide assay was modified from Haesslein and co-workers. ${ }^{24)}$. The samples were mixed and immediately put into cylindrical plastic molds (5-mm-height, 8-mm-diameter). Before complete setting, $1 \mathrm{~mL}$ of deionized (DI) water was poured onto the surface of each specimen. All specimens were kept at $37^{\circ} \mathrm{C}$. The conditioned media was collected at specified time intervals $(4 \mathrm{~h}, 8 \mathrm{~h}$, and $1,2,3,5,7,14,21$, and 28 days, and monthly afterwards) and replaced with the same amount of fresh DI water. The media samples were collected until the results showed a constant rate of release. The collected supernatant was stored at $2-8^{\circ} \mathrm{C}$ until analysis. The amount of released fluocinolone acetonide was determined by high performance liquid chromatography (HPLC) system equipped with a UV-VIS detector (Shimadzu, Model SPD-10A, Shimadzu Corp., Kyoto, Japan). In a typical run, $50 \mu \mathrm{L}$ of samples were analyzed on a reverse phase C18, $5 \mu \mathrm{m}$ column (250 $\mathrm{mm} \times 4.6 \mathrm{~mm}$ ) (Inertsil ${ }^{\mathrm{TM}}$, GL Sciences Inc., Tokyo,
Japan). A water-methanol mixture (30:70 by volume) delivered at a flow rate of $0.7 \mathrm{~mL} / \mathrm{min}$ was used as mobile phase. Fluocinolone acetonide was detected at a wavelength of $238 \mathrm{~nm}$ and an approximate retention time of $11 \mathrm{~min}$. Fluocinolone acetonide standards were prepared from a stock solution of fluocinolone acetonide in DMSO $(4.52 \mathrm{mg} / \mathrm{mL})$ by dilution with DI water. The concentration of standard was proportional to the integrated area of the corresponding peak in UV absorbance. The calibrated standard curve was linear $\left(\mathrm{R}^{2}>0.99\right)$ over the recorded concentration range of fluocinolone acetonide between 1 to $100 \mu \mathrm{mol} / \mathrm{L}$. Various concentrations of fluocinolone acetonide (10 to 150 $\mathrm{mmol} / \mathrm{L}$ ) were loaded into the cements. The amount of fluocinolone acetonide release was recorded, and a suitable concentration of fluocinolone acetonide loading was selected for further investigation. Ten experimental samples were prepared for each group. The cement without fluocinolone acetonide was used as a control. The release of fluocinolone acetonide was calculated and recorded in $\mu \mathrm{mol} / \mathrm{L}$.

\section{pH measurement}

The method of $\mathrm{pH}$ measurement was modified from Gençay and colleagues ${ }^{25}$. Each specimen was mixed and placed in a cylindrical stainless steel mold with 2-mm-height and 4-mm-diameter. Then, the mold and cement was pressed between two microscopic glass slides. The samples were allowed to set in room temperature. Each sample was taken out of the mold and placed into a separate vial, containing $10 \mathrm{~mL}$ DI water. The samples were stored at $37^{\circ} \mathrm{C}$, and $\mathrm{pH}$ measurement was done at $1,3,24,48,72$, and $168 \mathrm{~h}(7$ days) after the incubation. The $\mathrm{pH}$ value was measured by a digital $\mathrm{pH}$ meter (Orion Research 420A, Orion Research Inc., Boston, MA, USA), which connected to a glass electrode (Orion $\mathrm{Ag} / \mathrm{AgCl} 91$ Series electrode, Orion Research Inc.). The $\mathrm{pH}$ meter was calibrated with buffer solutions (Orion buffer solution, Perfect buffer 10, Orion Research Inc. $[\mathrm{pH}<7,00 ; \mathrm{pH}<11,00])$ before each experiment. Ten samples were prepared for each group. The $\mathrm{pH}$ values were shown as mean \pm standard deviation compared with the control.

Table 1 Experimental pulp capping material base and catalyst composition

Quantity (\%)

\begin{tabular}{lr}
\hline Base & 43.00 \\
1,3-Butylene glycol disalicylate & 9.00 \\
Zinc oxide & 31.00 \\
Titanium oxide-calcium phosphate & 17.00 \\
Calcium tungstate & 0.1 \\
Iron oxide pigment & 51.00 \\
Catalyst & 9.23 \\
Calcium hydroxide & 0.29 \\
Zinc oxide & 39.48 \\
Zinc stearate & \\
Ethyl toluene sulfonamide + Fluocinolone acetonide &
\end{tabular}




\section{Determination of setting time}

According to International Standard ISO 3107:2004, the cylindrical specimens were prepared from stainless steel molds with 2-mm-height and 10-mm-diameter. The mold was placed on a flat glass plate and filled with the mixed material. The molds and tested materials were placed on a metal block in a controlled chamber $\left(37^{\circ} \mathrm{C}\right.$ and $95 \%$ relative humidity) within $60 \mathrm{~s}$ from started mixing. A flat-ended indenter needle (100 g) was lowered vertically onto the surface of the cement. The indentation was immediately made at $15 \mathrm{~s}$ intervals in different area. The needle tip was cleaned before each indentation. The setting time was recorded as the period of time from the start of mixing to the time when the needle failed to completely penetrate the whole depth of material. Ten samples were tested for each group.

\section{Determination of compressive strength}

The method used in this study was carried out according to ISO 3107:2004 standard. Specimens were prepared from stainless molds with 4-mm-height and 6-mmdiameter. The cement was put in the mold and placed on a metal plate within 1 min after mixing. Another metal plate was placed on top and both plates were squeezed together. The whole assembly was transferred to the cabinet $\left(37^{\circ} \mathrm{C}\right.$ and $95 \%$ relative humidity) within $2 \mathrm{~min}$ after the end of mixing. One hour after the completion of mixing, flat surfaces of the specimen were prepared at $90^{\circ}$ to the long axis. The specimen was removed from the mold immediately and examined for voids or chipped edges. Any defective specimens were discarded. Ten specimens were used for the experiment in each group. The diameter of the cylinders was measured and recorded. The specimens were immersed in distilled water and maintained at $37^{\circ} \mathrm{C}$ for $24 \mathrm{~h}$, then conditioned in distilled water at $23^{\circ} \mathrm{C}$ for $15 \mathrm{~min}$ prior to test. The flat ends of each specimen were placed between the platens of universal testing machine (Instron, Model 8872; Instron corp., Canton, MA, USA). The compressive load was applied along the long axis of the specimen using cross-head speed of $1.00 \mathrm{~mm} / \mathrm{min}$ until fracture occurred. Then, the maximum force was recorded. The compressive strength was calculated from the relationship between surface area and load.

\section{Determination of disintegration}

The disintegration of test materials was examined according to ISO 3107:2004. Specimens were prepared from split stainless steel rings with 1.5-mm-height and 20-mm-internal diameter. The mold was placed on a thin cellulose acetate sheet backed by a flat glass plate. A stainless steel wire $(0.25$-mm-diameter) was inserted through the split ring at least $10 \mathrm{~mm}$ into the ring. The cement and Dycal ${ }^{\circledR}$ (as a control group) were mixed and filled in the ring, then, covered with another flat glass plate faced with a sheet of cellulose acetate, and firmly pressed together. After the complete set (approximately 3 min after the start of mixing), the molds and plates were placed in the cabinet maintained at $37^{\circ} \mathrm{C}$ and $95 \%$ relative humidity. Then, the specimens and attached wires were carefully removed from the ring. The excess cement was removed from the edge of the specimen disc, and lightly brushed to remove any loose material from the surface. The specimens were weighed and net weight of cement (total weight minus with stainless steel wire) was recorded. Two of the sample discs were placed in a $100 \mathrm{~mL}$ beaker. The discs were submerged immediately by pouring $50 \mathrm{~mL}$ of distilled water into the beaker. The specimens were suspended by the wire without contact to each other and to the beaker. Then, the beaker was sealed with plastic wrap and aluminum foil. After immersing the discs for $24 \mathrm{~h}$ at $37^{\circ} \mathrm{C}$, the specimens were removed from the water. Their surfaces were rinsed with $2 \mathrm{~mL}$ of distilled water. The surfaces were gently dried with clean absorbent paper. The specimens were then stored in a desiccator for $24 \mathrm{~h}$ and reweighed. The final net mass of cement was then recorded. The disintegration was calculated as percentage of the original weight. Ten samples were prepared from each group.

\section{Determination of acid-soluble arsenic content}

The method used in this study was examined according to ISO 3107:2004. The set experimental cement and Dycal $^{\circledR}$ (as a control group) were pulverized and passed through a $75 \mu \mathrm{m}$ (200 mesh) sieve. Two grams of the sieved powder was dispersed in $30 \mathrm{~mL}$ of water with 10 $\mathrm{mL}$ of $37 \%$ hydrochloric acid (Hydrochloric acid fuming 37\%, Merck KGaA, Darmstadt, Germany). The mixture was maintained at $37^{\circ} \mathrm{C}$ for $1 \mathrm{~h}$, and filtered. The total arsenic content of the sample was determined with the atomic absorption microscopy (AAnalyst 800, PerkinElmer Inc., Shelton, CT, USA). Ten samples were prepared from each group.

\section{Statistical analysis}

All data were analyzed by using a statistical analysis program (SPSS version 17.0, SPSS Inc., Chicago, IL, USA). The significant difference between material properties was determined by Student's $t$-test $(p<0.05)$. The data of setting time was discrete data. Therefore, it was shown as median and analyzed by Mann-Whitney $U$ test $(p<0.05)$.

\section{RESULTS}

\section{In vitro release of fluocinolone acetonide}

The amount of released fluocinolone acetonide was determined by HPLC and UV detection directly from the release media. The HPLC method allowed for the detection of fluocinolone acetonide at a retention time $11.0 \mathrm{~min}$ (Fig. 1a). The amounts of released fluocinolone acetonide from various concentrations of the experimental materials were presented in Fig. 1b. Cements with 50 $\mathrm{mmol} / \mathrm{L}$ fluocinolone acetonide loading could release fluocinolone acetonide at a concentration of $50 \mu \mathrm{mol} / \mathrm{L}$ from $50-\mathrm{mm}^{2}$-surface area which is equal to $1 \mu \mathrm{mol} / \mathrm{L} /$ $\mathrm{mm}^{2}$. Therefore, $50 \mathrm{mmol} / \mathrm{L}$ of fluocinolone acetonide loading was selected for further investigation.

The cumulative release of fluocinolone acetonide from the PCFA was investigated in the in vitro release 
(a)



(c)

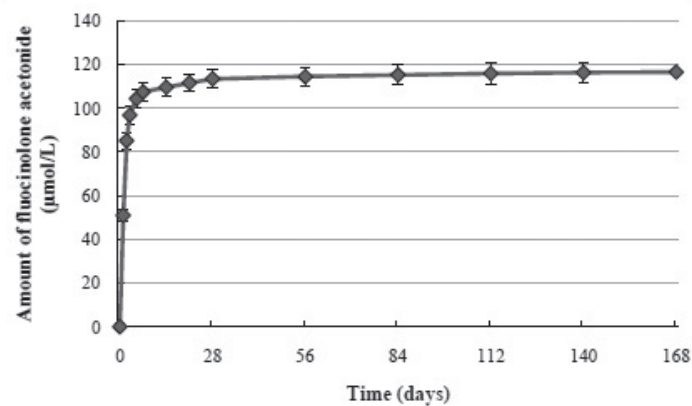

(b)



(d)



Fig. 1 Release of fluocinolone acetonide from experimental cement. (a) Chromatogram obtained from HPLC and peak of fluocinolone acetonide (arrow); (b) Selection of $50 \mathrm{mmol} / \mathrm{L}$ fluocinolone acetonide loading from various doses of experimental pulp capping materials; (c) Cumulative release of fluocinolone acetonide; and (d) Fluocinolone acetonide concentration released over each different periods of time. Data are represented as means \pm standard deviation.

study over 6 months. The result was shown in Fig. 1c as the $\operatorname{mean} \pm \mathrm{SD}$ of the released fluocinolone acetonide. Fluocinolone acetonide was dramatically released over the first $72 \mathrm{~h}$ (Fig. 1d). This early rapid release also affected the cumulative release of fluocinolone acetonide, especially in the first 5 days as shown in Fig. 1c. After 1 month, fluocinolone acetonide was released from the PCFA at an almost constant rate of $0.029-0.021 \mu \mathrm{mol} / \mathrm{L} /$ day.

\section{pH measurement}

The $\mathrm{pH}$ of the experimental material and Dycal ${ }^{\circledR}$ became increased from neutral after $1 \mathrm{~h}$. The $\mathrm{pH}$ of PCFA was significantly higher than that of $\mathrm{Dycal}^{\circledR}$ at every time interval $(p<0.05)$. The $\mathrm{pH}$ of $\mathrm{Dycal}^{\circledR}$ and PCFA ranged between 9.80 to 10.86 and 10.57 to 11.72 , respectively. The $\mathrm{pH}$ of both materials remained stable after $72 \mathrm{~h}$ as shown in Fig. 2.

Determination of setting time, compressive strength, disintegration, and amount of acid-soluble arsenic content

The physical and mechanical properties of the experimental material were examined and the results shown in Fig. 3. The setting time of Dycal ${ }^{\circledR}$ and PCFA ranged from 60 to $90 \mathrm{~s}$ and 115 to $165 \mathrm{~s}$, respectively. The median setting times of Dycal ${ }^{\circledR}$ and PCFA respectively

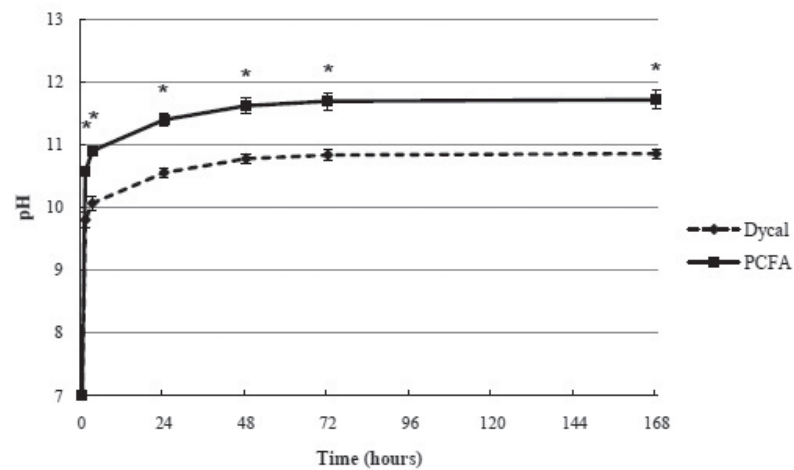

Fig. $2 \mathrm{pH}$ values of PCFA and Dycal $^{\circledR}$. Data are represented as means \pm standard deviation at each time interval. *Data show statistically significant differences between materials tested in corresponding method.

were 75 and $150 \mathrm{~s}$ (Fig. 3a). The compressive strength of Dycal $^{\circledR}$ and PCFA were 17.09 \pm 2.91 and $15.11 \pm 1.25 \mathrm{MPa}$, respectively (Fig. 3b). The disintegration of Dycal ${ }^{\circledR}$ and PCFA were $3.13 \pm 0.43 \%$ and $3.15 \pm 0.22 \%$ respectively (Fig. 3c). The compressive strength and disintegration of Dycal $^{\circledR}$ and PCFA were not significantly different 
(a)



(c)



(b)



(d)

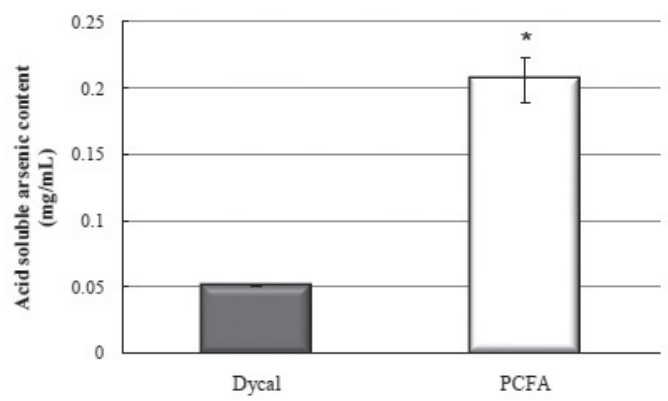

Fig. 3 Physical and mechanical properties of experimental cement (PCFA) and control (Dycal ${ }^{\circledR}$ ): (a) Setting time; (b) Compressive strength; (c) Disintegration; and (d) Acid-soluble arsenic content. Data of setting time is represented as median. The remaining data are represented as means \pm standard deviation. *Data show statistically significant differences between materials tested in corresponding method.

$(p<0.05)$. The acid-soluble arsenic content of Dycal ${ }^{\circledR}$ was less than $0.05 \mathrm{mg} / \mathrm{kg}$, whereas of PCFA was $0.21 \pm 0.02$ $\mathrm{mg} / \mathrm{kg}$ (Fig. 3d). The setting time and acid soluble arsenic content of PCFA were significantly higher than those of Dycal $^{\circledR}(p<0.05)$.

\section{DISCUSSION}

The use of anti-inflammatory agents for vital pulp therapy began in the 1960s. However, there have been questions about the safety of these medicaments. Fluocinolone acetonide has been demonstrated to be successful and safe to use in treatment of oral vesiculoerosive lesions ${ }^{19-21)}$. A limit number of evidence reported the positive proliferative effect of low range of concentrations of fluocinolone acetonide ${ }^{22,23)}$, but the inhibitory effect for cell growth is one of the well-known adverse effects of topical glucocorticoids ${ }^{26,27)}$. Thus, application of fluocinolone acetonide in vital pulp therapy was discouraged, and it should be used with cautions ${ }^{27)}$.

Our recent study showed the appropriate concentrations of fluocinolone acetonide in promotion of early healing response of pulp cells were $0.1-10 \mu \mathrm{mol} /$ $\mathrm{L}^{18)}$. Fluocinolone acetonide, therefore, was incorporated into the calcium hydroxide hard setting cement at the selected concentration $(50 \mathrm{mmol} / \mathrm{L})$ to release the suitable concentration. The chromatogram of HPLC showed several peaks of components of the PCFA, but most of them were too small. We could confirm the availability and stability of the released fluocinolone acetonide by comparison with the peak of the standard agent at the same retention time. The in vitro release study demonstrated fluocinolone acetonide was able to leach out from the material over a period of 6 months. The release of fluocinolone acetonide concentration, ranging from 0.1 to $1 \mu \mathrm{mol} / \mathrm{L}$, was found within the first 5 days. This period corresponds to the early phase of wound healing, the inflammatory and proliferative phases which start immediately and a few days after the treatment, respectively ${ }^{28-30)}$. Since 0.1 to $10 \mu \mathrm{mol} / \mathrm{L}$ fluocinolone acetonide has stimulatory effect on cell proliferation and extracellular matrix formation ${ }^{18)}$, the initial burst release of fluocinolone acetonide should be beneficial to healing. However, the activity of released fluocinolone acetonide is still not known and has to be confirmed by further in vitro and in vivo studies. Cell culture system can be used to study the effect of materials, with and without the release of fluocinolone acetonide, on cell proliferation, RNA and protein synthesis, or other cellular activities. The animal study must be done to confirm the healing of dental pulp tissue after capping with the PCFA or control. After 1 month, 
fluocinolone acetonide released from the PCFA at approximately $0.029-0.021 \mu \mathrm{mol} / \mathrm{L} /$ day. A minimal amount of fluocinolone acetonide released from the material is preferred over the long-term period to prevent both systemic effects of the steroid such as hyperglycemia, glaucoma, adrenal insufficiency, and local effects such as delayed wound healing and risk of microbial proliferation $^{26,27,31,32)}$.

Calcium hydroxide products have been accepted as a standard material for conservative treatment of dental pulp exposures due to their therapeutic and biological potential, their property of stimulating formation of sclerotic and reparative dentin, as well as protecting the pulp against thermal stimuli ${ }^{1)}$. The success obtained with calcium hydroxide as a pulp capping agent is related to its high alkalinity and it is suggested the rise in $\mathrm{pH}$ was the most important factor conductive to pulp healing ${ }^{33-37)}$. The conditioned media obtained from Dycal ${ }^{\circledR}$ had $\mathrm{pH}$ values of $9.80-10.86$ over the 168 -h (7 days) duration of this assay. This finding was in agreement with previous reports ${ }^{25,38-43)}$. The conditioned media obtained from PCFA also maintained high alkaline levels, with $\mathrm{pH}$ values of 10.57-11.72, which were significantly higher than those of Dycal $^{\circledR}$ during the 168-h (7 days) duration. This difference may be due to the different amount of hydroxyl ions released from each material. The higher $\mathrm{pH}$ value may have some advantages in neutralization of the acid at the site of inflammation, antibacterial effect, and stimulation of the repair and dentin bridge formation in the exposed pulp $p^{25,36,42,44)}$.

The ISO standard for a pulp capping material has not been developed. Therefore, ISO 3107:2004 was selected as a guideline for evaluation of the material properties. The setting time of the PCFA (150 s) was longer than that of Dycal ${ }^{\circledR}(75 \mathrm{~s})$. Earlier studies reported a longer setting time of Dycal ${ }^{\circledR}$ (145 s) which may be due to the different methods used among the studies ${ }^{39,45)}$. The setting time of the hard-setting calcium hydroxide is also affected by the room temperature. Therefore, the longer setting time of PCFA will be adequate for using at higher temperature condition. The compressive strength of PCFA (15.11 $\pm 1.25 \mathrm{MPa})$ was comparable to Dycal ${ }^{\circledR}$ $(17.09 \pm 2.91 \mathrm{MPa})$. Previous studies reported the compressive strength of Dycal ${ }^{\circledR}$ in a range of 14.5 to 36 $\mathrm{MPa}^{43,46,47)}$. However, the compressive strength of both cements was much higher than the minimal strength required by the ISO 3107:2004. They are strong enough to resist the average stress of $10.5 \mathrm{~N} / \mathrm{mm}^{2}$, which is applied through an amalgam condensation cycle ${ }^{48)}$. Disintegration of the PCFA (3.16\%) was equal to that of Dycal $^{\circledR}(3.13 \%)$ and was comparable to the previous reports of Dycal ${ }^{\circledR}(2.7 \text { to } 6.76 \%)^{39,49)}$. The solubility of the cement may be beneficial for the release of hydroxyl ions and fluocinolone acetonide, but it may cause the dissolution of the material and leave space under a restoration $^{49)}$. Due to the low compressive strength, disintegration and lack of adhesion to dentin, the cement should be used as a thin layer and covered by other base or liner material which provides a good seal and prevent the direct contact with acid etching procedure ${ }^{50)}$. The arsenic contamination in experiment cement (PCFA) was determined by the standard method. The test material was dispersed in acid until the contaminated arsenic was dissolved into the acid solution. The acid-soluble arsenic content of PCFA $(0.21 \mathrm{mg} / \mathrm{kg})$ was higher than that of Dycal $^{\circledR}(0.05 \mathrm{mg} / \mathrm{kg})$. This arsenic content in PCFA was approximately ten-fold below the maximal dose according to the ISO 3107:2004 standard and far below the lethal dose $(1.5$ to $500 \mathrm{mg} / \mathrm{kg}$ of body weight) administered orally in human ${ }^{51,52)}$.

Mineral trioxide aggregate (MTA) has been proven to be successful in vital pulp therapy. It can stimulate thick dentinal bridge and appears to have particular promise as a pulp capping material ${ }^{53-55)}$, even in cases of irreversible pulpitis ${ }^{56-58)}$. However, MTA has slow setting time and high cost. Some authors have reported the similar result between MTA and calcium hydroxide when used in human teeth ${ }^{33,59,60)}$. Although MTA is popular as a pulp capping material at present, it has different compositions and properties to the calcium hydroxide cements. Dycal ${ }^{\circledR}$ was chosen as the control in this study because of the similarity of type, composition, and usage. After the incorporation of fluocinolone acetonide into the experimental pulp capping material, fluocinolone acetonide could release and some physical and mechanical properties were not different from Dycal $^{\circledR}$. Therefore, PCFA may be considered as an alternative material in treatment of vital pulp or vital pulp therapy, instead of conventional calcium hydroxide cements. However, effect of fluocinolone acetonide or PCFA to dental pulp tissue is still not known. Further in vitro and in vivo experiments are required to confirm the biologic effect of this agent or material. Pulp tissue healing and quality of dentin bridge should be evaluated by comparison with MTA in an in vivo study before this material is introduced for clinical use.

\section{CONCLUSIONS}

The results from this study have shown that fluocinolone acetonide could release at suitable concentrations from the experimental anti-inflammatory calcium hydroxide cement. The $\mathrm{pH}$, setting time, and acid-soluble arsenic content were higher than Dycal ${ }^{\circledR}$, but the compressive strength and disintegration were not different from Dycal $^{\circledR}$.

\section{ACKNOWLEDGMENTS}

This study was supported by The Chulalongkorn University Centenary Academic Development Project from Chulalongkorn University, Bangkok, Thailand. The authors would like to thank Dr. Voravee P. Hoven for her support in chemical synthesis of base material, and Dr. Kevin Tompkins for his suggestions and criticism of this manuscript. 


\section{REFERENCES}

1) Modena KC, Casas-Apayco LC, Atta MT, Costa CA, Hebling J, Sipert CR, Navarro MF, Santos CF. Cytotoxicity and biocompatibility of direct and indirect pulp capping materials. J Appl Oral Sci 2009; 17: 544-554.

2) Schröder U. Effect of an extra-pulpal blood clot on healing following experimental pulpotomy and capping with calcium hydroxide. Odontol Revy 1973; 24: 257-268.

3) Costa CA, Hebling J, Hanks CT. Current status of pulp capping with dentin adhesive systems: a review. Dent Mater 2000; 16: 188-197.

4) Torabinejad M, Parirokh M. Mineral trioxide aggregate: a comprehensive literature review-part II: leakage and biocompatibility investigations. J Endod 2010; 36: 190-202.

5) Trope M, McDougal R, Levin L, May KN Jr., Swift EJ Jr. Capping the inflamed pulp under different clinical conditions. J Esthet Restor Dent 2002; 14: 349-357.

6) Ward J. Vital pulp therapy in cariously exposed permanent teeth and its limitations. Aust Endod J 2002; 28: 29-37.

7) Cannon M, Cernigliaro J, Vieira A, Percinoto C, Jurado R. Effects of antibacterial agents on dental pulps of monkeys mechanically exposed and contaminated. J Clin Pediatr Dent 2008; 33: 21-28.

8) Fachin EV, Scarparo RK, Pezzi AP, Luisi SB, Sant'ana Filho M. Effect of betamethasone on the pulp after topical application to the dentin of rat teeth: vascular aspects of the inflammation. J Appl Oral Sci 2009; 17: 335-339.

9) Rapoport L, Abramson II. Application of steroid hormones in pulp-capping and pulpotomy procedures; a preliminary report. Oral Surg Oral Med Oral Pathol 1958; 11: 545-548.

10) Ulmansky M, Sela J, Langer M, Yaari A. Response of pulpotomy wounds in normal human teeth to successively applied Ledermix and Calxyl. Arch Oral Biol 1971; 16: 1393-1398.

11) Komabayashi $T$, Zhu $Q$. Innovative endodontic therapy for anti-inflammatory direct pulp capping of permanent teeth with a mature apex. Oral Surg Oral Med Oral Pathol Oral Radiol Endod 2010; 109: e75-81.

12) Chidiac JJ, Al-Asmar B, Rifai K, Jabbur SJ, Saadé NE. Inflammatory mediators released following application of irritants on the rat injured incisors. The effect of treatment with anti-inflammatory drugs. Cytokine 2009; 46: 194-200.

13) Schroeder A, Triadan H. The pharmacotherapy of pulpitis. Oral Surg Oral Med Oral Pathol 1962; 15: 345-350.

14) Uitto VJ, Antila R, Ranta R. Effects of topical glucocorticoid medication on collagen biosynthesis in the dental pulp. Acta Odontol Scand 1975; 33: 287-298.

15) Barker BC, Ehrmann EH. Human pulp reactions to a glucocorticosteroid-antibiotic compound. Aust Dent J 1969; 14: 104-119.

16) Barker BC, Payne M, Warby HA. Two case reports: successful treatment of carious exposures with Ledermix. Aust Dent J 1972; 17: 144-146.

17) Clarke NG. The corticosteroid-antibiotic dressing as a capping for inflamed dental pulps. Aust Dent J 1971; 16: 71-76.

18) Muincharern $W$, Louwakul $P$, Pavasant $P$, Lertchirakarn $V$. Effect of fluocinolone acetonide on human dental pulp cells: cytotoxicity, proliferation, and extracellular matrix formation. J Endod 2011; 37: 181-184.

19) Buajeeb W, Pobrurksa C, Kraivaphan P. Efficacy of fluocinolone acetonide gel in the treatment of oral lichen planus. Oral Surg Oral Med Oral Pathol Oral Radiol Endod 2000; 89: 42-45.

20) Hooley JR, Hohl TH. Use of steroids in the prevention of some complications after traumatic oral surgery. J Oral Surg 1974; 32: 864-866.

21) Lozada F, Silverman S Jr. Topically applied fluocinonide in an adhesive base in the treatment of oral vesiculoerosive diseases. Arch Dermatol 1980; 116: 898-901.

22) Fisher LB, Maibach HI. The effect of corticosteroids on human epidermal mitotic activity. Arch Dermatol 1971; 103: 39-44.

23) Kirk D, Mittwoch U. Effects of topically potent glucocorticoids on human diploid fibroblasts in vitro. Br J Dermatol 1977; 97: 69-75.

24) Haesslein A, Ueda $H$, Hacker MC, Jo S, Ammon DM, Borazjani RN, Kunzler JF, Salamone JC, Mikos AG. Long-term release of fluocinolone acetonide using biodegradable fumarate-based polymers. J Control Release 2006; 114: 251-260.

25) Gençay K, Seymen F, Selvi S, Kiziltan B. In vitro evaluation of $\mathrm{pH}$ changes induced by calcium hydroxide liners. Quintessence Int 2004; 35: 560-562.

26) Hengge UR, Ruzicka T, Schwartz RA, Cork MJ. Adverse effects of topical glucocorticosteroids. J Am Acad Dermatol 2006; 54: 1-15; quiz 16-18.

27) Sinkford JC, Harris SC. The case against topical use of adrenocorticosteroids in dentistry. J Am Dent Assoc 1964; 68: 765-767.

28) de Souza Costa CA, Duarte PT, de Souza PP, Giro EM, Hebling J. Cytotoxic effects and pulpal response caused by a mineral trioxide aggregate formulation and calcium hydroxide. Am J Dent 2008; 21: 255-261.

29) Kitasako Y, Shibata S, Arakawa M, Cox CF, Tagami J. A light and transmission microscopic study of mechanically exposed monkey pulps: dynamics of fiber elements during early dentin bridge formation. Oral Surg Oral Med Oral Pathol Oral Radiol Endod 2000; 89: 224-230.

30) Kitasako Y, Shibata S, Tagami J. Migration and particle clearance from hard-setting $\mathrm{Ca}(\mathrm{OH}) 2$ and self-etching adhesive resin following direct pulp capping. Am J Dent 2006; 19: $370-375$.

31) Klotz MD, Gerstein H, Bahn AN. Bacteremia after topical use of prednisolone in infected pulps. J Am Dent Assoc 1965; 71: 871-875.

32) Watts A, Paterson RC. The response of the mechanically exposed pulp to prednisolone and triamcinolone acetonide. Int Endod J 1988; 21: 9-16.

33) Accorinte Mde L, Holland R, Reis A, Bortoluzzi MC, Murata SS, Dezan E Jr, Souza V, Alessandro LD. Evaluation of mineral trioxide aggregate and calcium hydroxide cement as pulp-capping agents in human teeth. J Endod 2008; 34: 1-6.

34) Lu Y, Liu T, Li H, Pi G. Histological evaluation of direct pulp capping with a self-etching adhesive and calcium hydroxide on human pulp tissue. Int Endod J 2008; 41: 643-650.

35) Staehle HJ, Pioch T, Hoppe W. The alkalizing properties of calcium hydroxide compounds. Endod Dent Traumatol 1989; 5: $147-152$.

36) Tamburić SD, Vuleta GM, Ognjanović JM. In vitro release of calcium and hydroxyl ions from two types of calcium hydroxide preparation. Int Endod J 1993; 26: 125-130.

37) Zander HA. Reaction of the pulp to calcium hydroxide. J Dent Res 1939; 18: 373-379.

38) Grajower R, Hirschfeld Z, Zalkind M. Observations on cavity liners for composite resin restorations. J Prosthet Dent 1976; 36: 265-273.

39) McComb D. Comparison of physical properties of commercial calcium hydroxide lining cements. J Am Dent Assoc 1983; 107: 610-613.

40) Niinuma A. Newly developed resinous direct pulp capping agent containing calcium hydroxide (MTYA1-Ca). Int Endod J 1999; 32: 475-483.

41) Prosser HJ, Groffman DM, Wilson AD. The effect of composition on the erosion properties of calcium hydroxide cements. J Dent Res 1982; 61: 1431-1435.

42) Subramaniam P, Konde S, Prashanth P. An in vitro evaluation 
of $\mathrm{pH}$ variations in calcium hydroxide liners. J Indian Soc Pedod Prev Dent 2006; 24: 144-145.

43) Tam LE, Pulver E, McComb D, Smith DC. Physical properties of calcium hydroxide and glass-ionomer base and lining materials. Dent Mater 1989; 5: 145-149.

44) Murray PE, Lumley PJ, Smith AJ, Ross HF. The influence of sample dimensions on hydroxyl ion release from calcium hydroxide products. Endod Dent Traumatol 2000; 16: 251-257.

45) Shen Q, Sun J, Wu J, Liu C, Chen F. An in vitro investigation of the mechanical-chemical and biological properties of calcium phosphate/calcium silicate/bismutite cement for dental pulp capping. J Biomed Mater Res B Appl Biomater 2010; 94: 141-148.

46) Draheim RN, Titus HW, Murrey AJ. A comparison of compressive strengths of six cavity base materials. J Prosthet Dent 1988; 60: 317-319.

47) Lewis BA, Burgess JO, Gray SE. Mechanical properties of dental base materials. Am J Dent 1992; 5: 69-72.

48) Plant CG, Wilson HJ. Early strengths of lining materials. Br Dent J 1970; 129: 269-274.

49) Hwas M, Sandrik JL. Acid and water solubility and strength of calcium hydroxide bases. J Am Dent Assoc 1984; 108: 46-48.

50) Bryant RW, Wing G. The rate of development of strength in base forming materials for dental amalgam. Aust Dent J 1976; 21: 153-159.

51) Bramante CM, Demarchi AC, de Moraes IG, Bernadineli N, Garcia RB, Spångberg LS, Duarte MA. Presence of arsenic in different types of MTA and white and gray Portland cement. Oral Surg Oral Med Oral Pathol Oral Radiol Endod 2008; 106: 909-913.

52) De-Deus G, de Souza MC, Sergio Fidel RA, Fidel SR, de
Campos RC, Luna AS. Negligible expression of arsenic in some commercially available brands of Portland cement and mineral trioxide aggregate. J Endod 2009; 35: 887-890.

53) Bogen G, Kim JS, Bakland LK. Direct pulp capping with mineral trioxide aggregate: an observational study. J Am Dent Assoc 2008; 139: 305-315; quiz 305-315.

54) Mente J, Geletneky B, Ohle M, Koch MJ, Friedrich Ding PG, Wolff D, Dreyhaupt J, Martin N, Staehle HJ, Pfefferle T. Mineral trioxide aggregate or calcium hydroxide direct pulp capping: an analysis of the clinical treatment outcome. J Endod 2010; 36: 806-813.

55) Nair PN, Duncan HF, Pitt Ford TR, Luder HU. Histological, ultrastructural and quantitative investigations on the response of healthy human pulps to experimental capping with mineral trioxide aggregate: a randomized controlled trial. Int Endod J 2008; 41: 128-150.

56) Barrieshi-Nusair KM, Qudeimat MA. A prospective clinical study of mineral trioxide aggregate for partial pulpotomy in cariously exposed permanent teeth. J Endod 2006; 32: 731-735.

57) Chueh LH, Chiang CP. Histology of Irreversible pulpitis premolars treated with mineral trioxide aggregate pulpotomy. Oper Dent 2010; 35: 370-374.

58) Eghbal MJ, Asgary S, Baglue RA, Parirokh M, Ghoddusi J. MTA pulpotomy of human permanent molars with irreversible pulpitis. Aust Endod J 2009; 35: 4-8.

59) Dammaschke T, Leidinger J, Schäfer E. Long-term evaluation of direct pulp capping--treatment outcomes over an average period of 6.1 years. Clin Oral Invest 2010; 14: 559-567.

60) Iwamoto CE, Adachi E, Pameijer CH, Barnes D, Romberg EE, Jefferies S. Clinical and histological evaluation of white ProRoot MTA in direct pulp capping. Am J Dent 2006; 19: 85-90. 